\title{
Trade Threats to Butterflies
}

\author{
D. F. Owen
}

In Britain there are no restrictions on collecting, importing, buying or selling of butterfiles, however rare or threatened, and a worldwide trade has developed that is still growing. One Kent dealer lists bird-wings at $£ 98$ a pair. The author urges the need for their protection. The situation underlines the urgency for the comprehensive wildlife protection bill, with schedules listing rare and endangered species of animals, insects and plants, referred to on page 403.

Butterfly collecting and the buying and selling of specimens is on the increase in Britain. In 1972 The Sunday Times gave details of how and where exotic butterfies could be bought, and suggested that the acquisition of specimens of beautiful butterflies could enhance memories of a holiday in an exotic part of the world. Dealers in butterflies not only sell rare and beautiful species but also produce and market butterfly jewelry made from the iridescent wings of spectacular Morphos from the forests of Central and South America. Even though many butterflies are rare and their habitats threatened by human destruction of the environment, there is nothing to prevent a dealer in Britain from buying and selling them, and there are no restrictions on importing dead specimens. The growth in this trade may be compared with that in birds' eggs fifty years ago. Nowadays it is illegal to take the eggs of most British breeding birds, but the only restrictions on butterfly collecting are in nature reserves where the collecting of all animals and plants is usually prohibited.

Butterflies are conspicuous and easy to collect. Many of the beautiful tropical species can be trapped with baits of rotten fruit. Dealers in Britain claim to have numerous contacts who can supply specimens and the trade is growing so fast that one dealer says that he can now reduce prices because there are so many new sources of specimens. Like many animals and plants in the tropics, butterflies are common as a group but each species may be relatively rare at least locally, and so extensive trapping and netting can substantially reduce populations. The danger of extinction is enhanced by the fact that many tropical environments are being radically altered by human activities; soon there will be no undisturbed rain forests of significant size left, and many rain-forest butterflies will disappear before anything is known of their natural history.

\section{Exotic tropical species}

The main demand is for large and showy species, and if they are rare so much the better; there seems little trade in small, dull-coloured species, even rare ones. Butterflies are bought by people who might otherwise be collecting postage stamps. One of Britain's biggest 
dealers has not only produced a splendid catalogue with colour photographs of specimens for sale, but also colour pictures of butterfly jewelry, including rings, necklaces, brooches, cuff-links, key-chains, and table mats, all containing whole butterflies or pieces of wing. These are presumably aimed at the buyer who likes pretty and unusual things about the house or about his or her person.

No doubt some of the specimens at present being sold are derived from old collections, some of which were very large indeed and often contained proportionately more of the large showy species. These are constantly coming up for auction and a knowledgeable dealer can acquire them for quite a small sum. But much more alarming is the increase in the number of 'contacts' abroad who are able and willing to supply dealers with large quantities of 'papered' specimens which are subsequently sold, either while still in papers or after they have been properly pinned and mounted. Dealers are constantly seeking new sources of material. When I worked in West Africa I received many requests from a variety of countries, especially Britain, the United States, and Japan; all insisted that the specimens should be in perfect condition (damaged ones being obviously more difficult to sell) and should be large and showy. One wrote,

Gentlemen, we are trying to reach missions and missionaries in your section who might be able to supply us with butterflies. I am sure you know someone who might be interested in earning money in his spare time, as we pay from five cents each for common, to many dollars for rare butterflies. ... . Many students can earn enough money in his spare time to help pay for his education. (sic) You might have some men in your school who might be interested. ... Enclosed, find simple instructions and a few paper envelopes used for butterflies.

In Africa most of the people who collect butterflies for sale to dealers are Europeans. This is partly because the dealer rarely offers money in advance, and Africans who might otherwise collect rarely have capital for the initial costs of equipment and postage. Missionaries in particular seem especially liable to take up collecting for profit, but even relatively affluent people will do so-I know a medical doctor employed by the World Health Organization who collects for dealers.

\section{British butterflies}

There are only 56 resident butterfly species in the British Isles, and of these I estimate that 20 are threatened by the activities of dealers and collectors. Another species, the large copper, became extinct in Britain about 1848 as the result of over-collecting, although it has subsequently been successfully reintroduced and may not be collected, being in a nature reserve. Particularly vulnerable species are those forming discrete local colonies. An examination of the Nature Conservancy's recently published provisional atlas giving the past and present distribution of the 56 resident species shows that many enjoyed a much wider range in the past, and although it may be that other factors, such as changes in the pattern of land utilisation and the use of pesticides, have caused 
this contraction of their range, it seems likely that collecting has contributed. With the reduction in the number of rabbits following myxomatosis, the chalk and limestone downs, which provide habitats for several local butterflies, lost much of their distinctive closecropped vegetation and became overgrown with grasses and shrubs. As a result, butterflies, including chalkhill blue, Adonis blue and silver-spotted skipper, which for centuries had flourished on the downs, became scarce and in some places disappeared. Others, including the Lulworth skipper, the Glanville fritillary and the large blue, have for many years been extremely local, confined to a few localities in the south where they are on the edge of their natural range in Britain, yet the demand for these is increasing. British-taken specimens of the swallowtail, now confined to the Norfolk Broads, are offered at £5 a pair, and many of the blues, which are notoriously variable in colour and markings, sell easily, especially to collectors interested in varieties, or 'aberrations' as they are called in the trade.

It could be argued that the entire British fauna is now under considerable pressure from expanding human populations and needs, and that to pick on butterfiles for special conservation measures will do little to improve an already bad situation. But butterflies, like birds, are conspicuous and beautiful, and unlike many other animals they can be enjoyed by even the casual visitor to the countryside. For these reasons alone it would seem appropriate to give them the kind of protection now given to birds and their eggs. The best possible solution is of course to conserve habitats, but some of the most threatened species survive in areas which are neither nature reserves nor specially protected. As the law stands there is little to prevent a collector from taking hundreds of specimens of one of the local species of blue and reducing its numbers to such an extent that it never recovers. I know areas in Kent where this has happened in the past, and I have no reason to suppose that the situation is substantially better today. The recent revival in trading specimens has brought real dangers to Britain's butterfly fauna, dangers which could be averted by giving complete protection to all those species of local distribution whose numbers are at best precarious, and by stopping all trade in them.

The following 20 species seem to me to be worthy of special protection. Not all are equally endangered; some have a wider distribution than others, and I have therefore starred* those which, because of their very local occurrence and tendency to form colonies, are especially easy to collect.

$\begin{array}{ll}\text { Lulworth skipper* } & \text { Mountain ringlet* } \\ \text { Swallowtail* } & \text { Silver-spotted skipper* } \\ \text { Black hairstreak* } & \text { Wood white } \\ \text { Adonis blue* } & \text { Silver-studded blue } \\ \text { Duke of Burgundy } & \text { Small blue } \\ \text { Fritillary } & \text { Purple emperor } \\ \text { Heath fritillary* } & \text { Glanville fritillary* }\end{array}$

Scotch Argus

Chequered skipper*

Brown hairstreak

Chalkhill blue

Large blue*

Large tortoiseshell

Marsh fritillary 
The remaining 36 British species are reasonably common. Some, such as the small white, whose caterpillars feed on cabbage, are exceedingly abundant, and the small tortoiseshell, which feeds on nettles, is found almost everywhere. These and a few others have become adapted to the environment of modern Britain and their future seems assured, but if we are to keep the less adaptable species protection is essential.

The Joint Committee for the Conservation of British Insects has issued a list of twelve species which it considers endangered and recommends that all but one of these should be collected 'with the greatest restraint' and that 'a pair of specimens is sufficient'. It suggests that the large blue should not be collected at all, and that local 'forms' of two other species should also be regarded as endangered. All but one (the large heath) appear on my list, but the Committee has no legal backing and, except in the case of the reintroduced large copper, which is in a nature reserve, there is nothing to prevent a ruthless collector taking as many as he likes.

\section{The Butterfly Business}

There is little doubt that the world trade in butterflies is very large indeed and growing even larger. The butterfly trade is most developed in the Far East, and the large and beautiful bird-wing butterflies are especially threatened, just as was the case with the birds of paradise in the same region some years ago. New Guinea has a law which prohibits the collection of bird-wings, but specimens continue to arrive in Britain, not only from New Guinea, but from other islands in the region.

Taiwan has for long been a centre of supply, and it is believed that the trade, which may run into millions of pounds a year, is a substantial earner of foreign exchange for that country. According to Nigel Sitwell (New Scientist, 11 th September, 1969) the enterprise was praised by a British cabinet minister as being an ingenious example of a cottage industry.

Retail prices in Britain vary unexpectedly and incomprehensibly. A dealer in Kent is currently offering a pair of Charaxes anticlea, a common African species, for $£ 9$, other rarer Charaxes for up to $£ 45$ a pair, and some of the bird-wings for up to $£ 98$ a pair. Many specimens sell for 40 or 50 pence each. Much would seem to depend on availability, but also on size and beauty, and some prices seem quite arbitrary. Another dealer in Britain offers to buy African Charaxes from collectors in the field for between 10 and 40 pence each. Evidently there is a constant demand for tropical species, provided they are large and showy and in good condition, and indeed many aspects of the butterfly business are similar to the buying and selling of postage stamps.

\section{What Can be Done?}

Conservationists in Britain are quick to condemn the people and governments of other countries for failing to protect wildlife, and yet in Britain it is perfectly legal to buy and sell butterflies, whether 
British or foreign. There are no restrictions on the importation of specimens and none on buying and selling even the rarest species. It might be difficult to discover the volume of trade in Britain, but if such information became available, it would then be possible to consider restrictions. The countries from which many of the butterflies come cannot be expected to do anything - they are often too concerned with other more pressing matters to worry about butterflies-but if the demand were to cease there would no longer be a market for field collectors to sell their specimens. It does seem that unless action is taken quickly we shall be in the same embarrassing position with butterflies as we are, for example, with the large mammals of Africa: their numbers were reduced by needless slaughter, and now we Europeans are trying with understandably limited success to persuade the people and governments of the independent African nations that they have a world heritage which must be conserved at all costs. If on occasion our pleas for conservation fall upon deaf ears we have only ourselves to blame.

\section{Butterflies of the World, by H. L. Lewis. Harrap, $£ 10$.}

This exceptionally well-produced book shows about 5000 species of butterflies in full colour arranged by the major biogeographical regions of the world. It provides at a glance a view of the world's butterfly fauna; you can see, for example, that the butterflies of Africa and tropical Asia are similar, that those of South America are distinct from all others, and that many European species have North American counterparts. You can see also that butterflies are essentially tropical and that western Europe is rather poor in species. The photographs are of specimens in the British Museum's magnificent collection, built up chiefly by amateurs; indeed looking through the book is rather like a visit to a museum.

That is the trouble. For the illustrations are likely to bring out the collector's instinct in even the most ardent conservationist. Butterflies are beautiful creatures, and so many colourful photographs of pinned specimens set in an unnatural position create a desire to collect. Would it not have been possible to have assembled at least a selection of photographs of living butterflies in their natural surroundings? This would remind us that butterflies are living animals and not something akin to postage stamps.

Nevertheless the author has given us a splendid feast of about half the world species, and the book is a delight to thumb through, pausing over this or that continent and its butterflies. The text is brief and rather superficial and, apart from a note or two about distribution, could easily have been omitted.

D. F. OWEN

Key to North American Waterfowl, by Stephen R. Wylie and Stewart S. Furlong (Livingstone, Wynnewood, $\mathrm{Pa}, \mathbf{\$ 3 . 9 5}$ ), is a booklet in the new waterproof and washable plastic material that can be taken into the field and dropped in water without coming to any harm. It is not a key in the ordinary sense. It consists entirely of an ordinal series of colour pictures of ducks, geese and swans, with no descriptions, but details of flight patterns and food and habitat preferences. It will nonetheless be useful to North American wildfowlers. 